\title{
Komunikat na temat diagnostyki rezonansu magnetycznego u pacjentów ortodontycznych Message about magnetic resonance diagnostics in orthodontic patients
}

\author{
Wspólne stanowisko Polskiego Towarzystwa Ortodontycznego (PTO), \\ Polskiego Lekarskiego Towarzystwa Radiologicznego (PLTR) \\ i Polskiego Towarzystwa Stomatologicznego (PTS)
}

Obrazowanie za pomocą rezonansu magnetycznego (MR) jest coraz powszechniej stosowaną metodą diagnostyczną. Ze względu na wątpliwości dotyczące bezpieczeństwa wykonywania badań MR u pacjentów leczonych ortodontycznie lub noszących stałe aparaty retencyjne, przedstawiamy wspólne stanowisko towarzystw PTO, PLTR, PTS, odnoszące się do możliwości badania MR u tej grupy pacjentów. Przedstawione rekomendacje dotyczą aparatów rezonansu magnetycznego o natężeniu pola do 3T włącznie. Zalecenia powinny być stosowane we wszystkich grupach wiekowych.

Podczas badania MR pole magnetyczne może mieć znaczny wpływ na materiały magnetyczne stosowane w celach medycznych (leczniczych), także w jamie ustnej pacjenta. Taka sytuacja ma miejsce w grupie pacjentów ortodontycznych. Podczas badania pole magnetyczne może wpływać na stalowe elementy aparatu ortodontycznego/ retencyjnego takie jak: zamki ortodontyczne, łuki, pierścienie, stałe retainery, nie przekraczając jednak siły wiązania tych elementów ze szkliwem. Przy prawidłowo umocowanych elementach aparatu, ryzyko przemieszczenia ich w trakcie badania MR jest znikome.

Pole magnetyczne nie wpływa negatywnie na elementy ze stopów tytanowych, NiTi, TMA; Cr-Co, miedzianych oraz na zamki ceramiczne lub z tworzyw sztucznych $(1,2)$.

Największy niepokój i kontrowersje budzi możliwość efektu termicznego pola magnetycznego na metal. Aparat ortodontyczny/retencyjny może się nagrzewać w trakcie badania. W najnowszych doniesieniach stwierdzono, że wzrost temperatury elementów aparatu ortodontycznego, znajdującego się w polu magnetycznym do $3 \mathrm{~T}$, nie przekracza $1^{\circ} \mathrm{C}$ podczas badania. Podwyższenie temperatury o 1 stopień nie ma wpływu negatywnego na szkliwo, miazgę zęba oraz otaczające tkanki miękkie $(3,4,5)$.

Istotnym problemem, który często utrudnia lub uniemożliwia ocenę badania MR, są artefakty, wynikające z obecności aparatu ortodontycznego/retencyjnego. Największe artefakty powstają w sąsiedztwie aparatu ortodontycznego/retencyjnego w rejonie żuchwy, podniebienia twardego, podstawy języka, nosogardła, w przypadku niektórych aparatów także płatów czołowych mózgu, okolicy siodła tureckiego oraz gałek ocznych. Stopień zaburzenia pola magnetycznego zależy od budowy aparatu ortodontycznego/retencyjnego: stopy tytanowe, chromowokobaltowe jak również elementy ceramiczne i tworzywa sztuczne nie powodują artefaktów w polu magnetycznym o natężeniu do 1,5 T $(6,7)$. Stalowe stopy mogą być źródłem artefaktów, których wielkość zależy rodzaju stopu stali i natężenia pola magnetycznego (im wyższe pole magnetyczne tym silniejsze artefakty). Stop stali 18-8 (zawierający około 18\% chromu i $8 \%$ niklu) nie wykazuje właściwości magnetycznych i nie powoduje artefaktów.

Wpływ na badanie MR mają także retainery, które zazwyczaj wykonane są ze stopów stalowych, powodujących powstanie artefaktów. Retainery tytanowe lub z materiałów z włókna szklanego nie mają wpływu na jakość obrazu MR.

\section{Podsumowanie}

- Prawidłowo umocowane elementy metalowe aparatów ortodontycznych nie ulegają przemieszczeniu w trakcie badania MR w skanerach o natężeniu pola magnetycznego do 3T.

- W trakcie badania może dojść do nieznacznego podniesienie temperatury (o $1^{\circ} \mathrm{C}$ ), co nie stanowi zagrożenia dla żywotności miazgi i otaczających tkanek.

- Stopy stali powodują powstanie miejscowych artefaktów w obrazie MR (z wyjątkiem stopu 18-8). Natomiast stopy niklowo-tytanowe, tytanowe, tytanowo-molibdenowe, chromowo-kobaltowe zamki ceramiczne i z tworzyw sztucznych nie powodują artefaktów w badaniu do 1,5 T.

- Przed wykonaniem badania lekarz ortodonta powinien zdjąć wszystkie ruchome elementy aparatu ortodontycznego (łuki, ligatury, łuki podniebienne) oraz sprawdzić czy pozostałe elementy są prawidłowo umocowane. Nie ma bezwzględnych wskazań do usuwania całego aparatu ortodontycznego.

- W wyjątkowych sytuacjach, gdy artefakty nie pozwalają na prawidłową ocenę badanych obszarów twarzoczaszki lub mózgowia należy usunąć cały aparat ortodontyczny.

- Obecność aparatu ortodontycznego nie ma wpływu na jakość badania MR odległych części ciała. 


\section{REKOMENDACJE PTO, PTS, PLTR BADANIE MR U PACJENTA ORTODONTYCZNEGO}

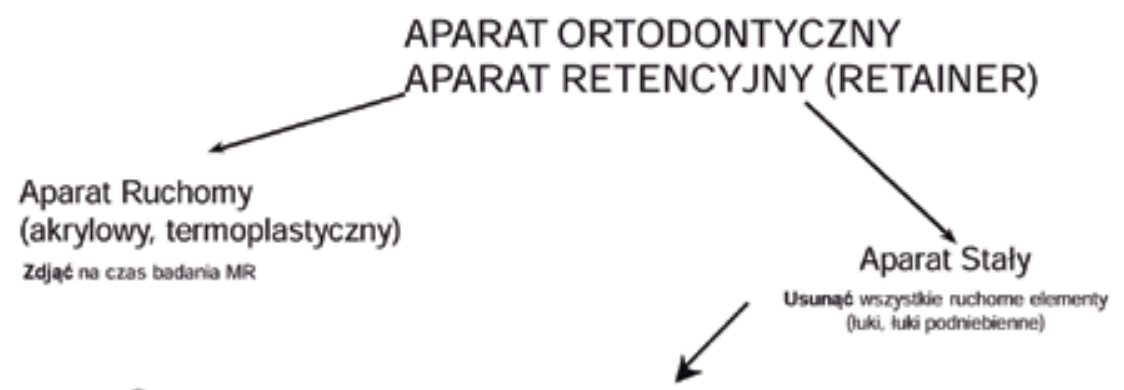

Q. Sprawdzić, czy stale elementy aparatu lub retainera są mocno przyklejone

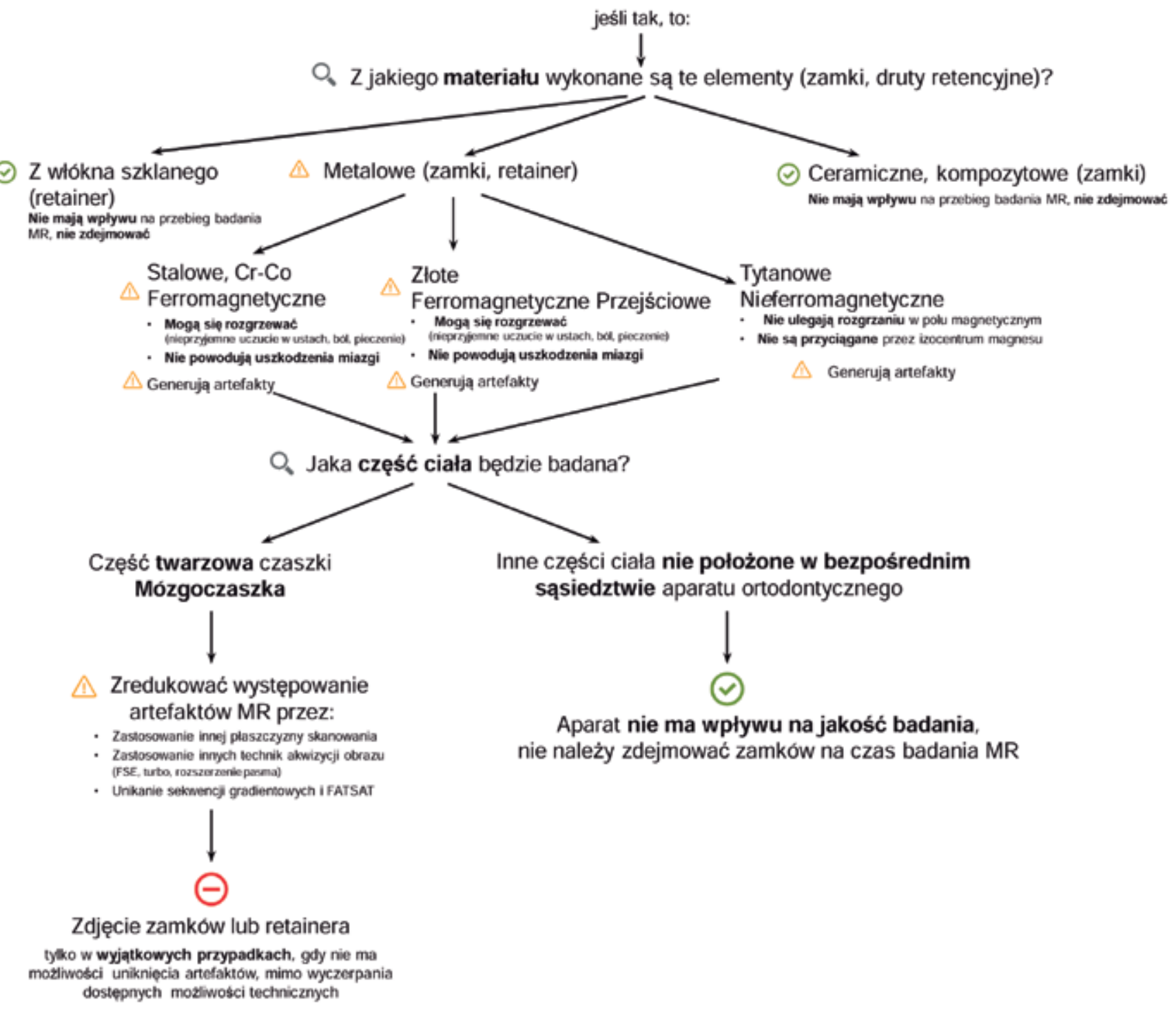




\section{Piśmiennictwo}

1. Kemper J, Klocke A, Kahl-Nieke B, Adam G. Orthodontic Brackets in High Field MR Imaging: Experimental Evaluation of Magnetic Field Interactions at 3,0 T. Fortschr Röntgenstr 2005; 177: 1691-8.

2. Klocke A, Kemper J, Schulze D, Adam G, Kahl-Nieke B. Magnetic Field Interactions of Orthodontic Wires during Magnetic resonance Imaging (MRI) at 1,5 Tesla. J Orofac Orthop 2005; 66: 279-87.

3. Regier M, Kemper J, Kaul MG, Feddersen M, Adam G, KahlNieke B, Klocke A. Radiofrequency-induced Heating near Fixed Orthodontic Appliances in High Field MRI Systems at 3.0 Tesla. J Orofac Orthop 2009; 70: 485-94.

4. Yassi K, Ziane F, Bardienet E, Moinard M, Veyret B, Chateil JF. Evaluation of the risk of overheatingand displacment of orthodontic devices in magnetic resonance imaging. J Radiol 2007; 88: 263-8.
5. Görgülü S, Ayyldz S, Kamburoğlu K, Gökçe S, Ozen T. Effect of orthodontic brackets and different wires on radiofrequency heating and magnetic field interactions during 3-T MRI. Dentomaxillofac Radiol 2014; 43: 20130356.

6. Elison MJ. Leggitt VL, Thomson M, Oyoyo U, Wycliffe ND. Influence of common orthodontic appliances on the diagnostic quality of cranial magnetic resonance images. Am J Orthod Dentofacial Orthop 2008; 134: 563-72.

7. Blankenstein F, Troung BT, Thomas A, Thieme N, Zachriat C. Predictability of magnetic susceptibilty artifacts from metalic orthodontic appliances in magnetic resonance imaging. J Orofacial Orthop 2015; 76: 14-29

Prof. Ingrid Różyło-Kalinowska p.o. Kierownik Samodzielnej Pracowni Propedeutyki Radiologii Stomatologicznej i Szczękowo-Twarzowej Uniwersytetu Medycznego w Lublinie ul. Karmelicka 7, 20-081 Lublin

Dr n. med. Beata Walawska

NZOZ Ortomix

Bursaki 25, 201-50 Lublin

Dr n. med. Agnieszka Predko-Engel

Stomatologia Predko-Engel

ul. Waszyngtona 32/19,15-304 Białystok

Dr hab. n. med. Elżbieta Jurkiewicz

Zakład Diagnostyki Obrazowej Centrum Zdrowia Dziecka

Al. Dzieci Polskich 20, 04-730 Warszawa

Prof. Andrzej Urbanik

Katedra i Zakład Radiologii Collegium Medicum Uniwersytet Jagielloński ul. Kopernika 19, 31-501 Kraków 